\title{
Activating Background Knowledge: An Effective Strategy to Develop Reading Comprehension Skills
}

\author{
Shubhada K. Deshpande \\ Asst. Professor, Vikas College of Arts, Science\& Commerce, \\ Vikhroli (East), Mumbai, India \\ e-mail:shubh.deshpande@rediffmail.com
}

\begin{abstract}
The present paper is a report on a small classroom based research study. The researcher has tried Activating Background Knowledge as a strategy to improve reading comprehension skills of the students in the First Year B.Com. Classroom in a degree college affiliated to the University of Mumbai. The teacher-researcher assigned two passages dealing with two different social issues and set in two different contexts, i.e., foreign and local, for comprehension to the students in the classroom. The classroom experience indicated that activating and building on the students' background knowledge did help in facilitating their reading comprehension skills. The paper thus recommends it as an effective strategy to develop the students' reading comprehension skills.

Keywords: background knowledge, reading comprehension, strategy
\end{abstract}




\section{INTRODUCTION}

As Halliday (1974) has rightly opined, learning language in relation to its context helps in learning how it operates as a system. The grammatical systems in a language are understood more meaningfully when it is read in relation to its meaning hidden in the social contexts and behavioural settings. Instead of teaching them to manipulate these structures, the teacher is thus encouraged to help the learners to develop strategies of the target language in association with their communicative functions in real situations and real time.

The Communicative approach to Language Teaching values the experience and the background knowledge of the learner as very important factors contributing to the learning process of the learner. The learner is thus looked upon as an intelligent, problem solving individual rather than as an empty receptacle forced to learn the structural systems in the language. According to Fries (1963 cited in Carrell, Devine and Eskey, 2000), comprehending a passage strongly requires on the part of the reader an establishment of relation between the text and the cultural factors. Rivers (1968 cited in Carrell, Devine and Eskey, 2000) also emphasizes the importance of an association between culture and language as it can help a nonnative reader in understanding the meaning of a text to its fullest.

Research in the area has proved the importance of the reader drawing upon his/her own experiences, background knowledge in the act of comprehending what s/he reads. The present paper is an outcome of a small scale classroom study by the researcher conducted in order to explore the possibilities of using Activating Background Knowledge as a strategy to facilitate reading comprehension skills of the learners.

\section{LITERATURE REVIEW}

Adams and Bruce (1980 cited in Johnson D.D, 1984) argue, that "Without prior knowledge, a complex object, such as a text, is not just difficult to interpret; Strictly speaking, it is meaningless."

One certainly needs to refer to Goodman's (1970) concept of reading as a 'psycholinguistic guessing game'. According to Goodman, reading is a cyclical process. A good reader exploits the redundancy inherent in language which helps him/her in reconstructing the whole text. Reconstruction is followed by the testing of its accuracy against previous information which can be a combination of information extracted from a text as well as his/her own background knowledge on the topic of a text. Once the agreement between the reconstruction and previous knowledge is confirmed by the reader, there once again starts the cyclical process of sampling. If any inconsistency or inaccuracy is observed in the reconstruction of the text, the reader either rereads the text or may not believe the information (Goodman1971 cited in Johnson, P., 1982).

The psycholinguistic theory thus confirmed an active participation of the reader in the process of comprehension, 'making and confirming predictions, primarily from his or her background knowledge of the various linguistic levels' (Carrell, Devine and Eskey, 2000). 
In 1979, Coady further enhanced this association between the background knowledge and the text by ascertaining the importance of an interaction between the ESL reader's background knowledge and conceptual abilities thus leading to processing of strategies resulting into comprehension.

As Anderson, Spiro and Anderson (1978) put it, schemata or knowledge structures serve as frameworks for related concepts.(Johnson, D.D., 1984).It is, therefore, necessary at this juncture to refer to the concept of schemata or schema which was first used by Kant (1781) to refer to the rules organizing 'smaller units of perception into larger unitary wholes'. According to Rumelhart (1980), schemata can represent knowledge at all levels- ideologies, cultural truths, knowledge about the meaning of a particular word, knowledge about what patterns of excitations are associated with what letters of the alphabet.' Meurer (1991) mentions schema as patterns representing the way experience and knowledge are organized in the mind and that schemata are powerfully used by readers in understanding information which is explicit as well as implicit in the text. Moreillon (2007) discusses schema as the mental structures used by an individual to store available information about 'people, places, objects or activities.'

For Rumelhart (1980), schemata referred to building blocks of cognition. These schemata are used by a reader in interpreting sensory data, in retrieving information from memory, in organizing actions and in guiding the flow of comprehension processing. According to Pritchand (1990 cited in WENG, 2012), the learner's schema full of background knowledge of cultural familiar materials facilitates the understanding of the text. Johnson and Pearson (1982) therefore define reading comprehension as the process of using prior knowledge and the cues provided by the writer to construct a model of the meaning of the text which hopefully bears some resemblance to the author's intended meaning.

However, Carrell and Eisterhold (1983) have rightly stated that the schema in order to be functional in the process of comprehension, needs to be activated. Moreillon (2007) has thus rightly included Activating Background Knowledge in the seven strategies of reading comprehension. Langer (1981) developed a Pre-Reading Plan (PReP) to help students activate prior knowledge before reading. The plan also helped the teacher in getting an awareness of the level of knowledge students possessed about a topic before reading. The plan includes:

- Eliciting free associations to a word or phrase from the reading material and writing it on the board,

- Asking students to reflect on the initial association, telling why they thought of the associations they had made, and

- Asking them to talk about any new ideas that have resulted from the activity.

Johnson (1982) has investigated the effects of building background knowledge on reading comprehension. Though from a different angle, Zhaohua (2004) has also focused on providing background knowledge as a strategy to facilitate reading comprehension. WENG (2012) has examined the relationship between background knowledge and language proficiency in reading comprehension. 
However, the importance of background knowledge in reading comprehension has been questioned by some researchers. Hudson (1982) and Carrell (1984) have argued that background knowledge may not have any significant effect on the advanced learners' comprehending of a passage. Rahman and Bisanz (1986) believed that background knowledge played more a crucial role in good readers than in poor readers. They suggested that the schema of poor readers may not develop and may not be used as efficiently as the schema of good readers.

As against this position, Johnston (1983) was of the opinion that poor comprehension could be the result of some type of mismatch between the reader's background knowledge and the text. Rumelhart further provides three possible reasons for failure to understand a passage:

- Lack of appropriate schema on the part of the reader,

- Failure on the part of the author to offer adequate clues to suggest to the existing schema,

- Failure on the part of the reader to build an exact interpretation as intended by the author.

Moreillon refers to Rosenblatt's theory (1978) which mentions reading as a transaction among the reader, the text and the intention of the author. According to Rosenblatt, background knowledge of each reader plays an important role in his/her act of reading as his/her feelings, personality and experiences do help the reader in interpreting the text.

As Moreillon (2007) puts it, to know about the schema of the learners, the teacher needs to take recourse to brainstorming and questioning about the prior ideas and information they have. If the learners do not have a schema, the teacher should help them build background knowledge. The learners need to be guided and helped in the assessment of their background knowledge by the teacher who can do it by modelling and practicing prior knowledge assessment. They can be helped by the teacher by sharing how his/her own background knowledge helps him/her in comprehension of the text.

Drawing from all of these ideas, the researcher felt that this theory was particularly applicable to the Indian setting where learners sometimes find it difficult to comprehend reading material on account of a lack of familiarity with background concept. In fact the researcher strongly felt that this way of activating background knowledge would be especially valuable for poor readers who belong to a vernacular medium of instruction at school. The researcher therefore decided to activate the learners' background knowledge as a means of facilitating reading comprehension in the Indian classroom setting.

\section{RESEARCH METHOD}

In order to explore the possibility of helping the learners in improving their reading comprehension by activating their background knowledge, the researcher tried the methodology suggested by Moreillon (2007) in a classroom of a degree college affiliated to the University of Mumbai. Most of the subjects belonged to the regional medium background. It was a classroom for students studying in the first 
year of B.Com. degree course. A total of 60 students were assigned two passages for comprehension. The passages were handed out to the students and they were allowed to briefly glance at them in order to obtain the general gist. The teacherresearcher used a series of questions to activate background knowledge, helping the students to relate the discussion of these questions to their reading of the actual passages.

The teacher researcher used two passages, both of which are reproduced at the end of this paper. One of the two passages was based on an American social issue, culturally and socially foreign to them. The other passage was also about a social issue familiar to them as it was from the context to which they belonged. The first passage dealt with the issue of social violence involving teenagers as offenders. Though the social problem dealt with was of universal nature, the context in which the passage presented it was alien to the students. Though taking place in the present times, certain vocabulary, especially suitable to the American context made comprehension difficult for the students. The other passage, dealing with the problem of early marriages, an issue particularly concerning the Indian society, sounded more familiar to the students due to its contextual similarity. However, almost equal extent of complexity was experienced by them with the language. Though the author had used simple language, semantically it was laden with messages that required reading between the lines, a difficult activity for the students considering their level of interpretation.

Neither of these passages formed part of the prescribed text for these students but were a part of the supplementary material used by the teacher in the classroom. The passages were followed by a series of comprehension questions.

Keene and Zimmerman (1997 cited in Moreillon, 2007) mention that the readers relate their background knowledge to the textual information in three ways : text-to-self, text-to-text and text-to-world. A teacher can use questions related to each of these types of connection to engage them in active reading.

The researcher chose to make use of think aloud questioning in order to model the text-to-self questions. This was because posing and answering questions could help them comprehend the passage through background knowledge accessible to them. The following questions were framed and asked to bring alive the student's text-to-self interaction focusing on the three areas: feelings, experiences and ideas. For both the passages, the researcher planned to use questions framed on similar lines with an objective to explore whether the same technique of using think aloud questions can help them comprehend a text dealing with an issue belonging to an unfamiliar context, as well as it could with a text grounded in a familiar context.

- Did you ever have an experience in the family or in the close relations in connection with the topic being discussed in the passage? Describe what happened and how you felt at that time.

- Can you draw any similarities/parallels/comparisons between your/your family members'/relatives' experience and the issue/experience that is being discussed in the passage?

- Have you ever heard of or read about any information related to this topic before? What is your opinion about it? 
While devising the questions for activating the text-to-text interaction in the students, the researcher thought of referring to books, newspaper based documents, oral communication, visual images or electronic images that the learners had $\mathrm{read} /$ watched with a similar theme and which could be compared with this text. The following types of questions were posed for this interaction to be possible:

- Have you ever read a book or seen a movie with the theme similar to the one being discussed in this passage? Describe the similarity between the two.

- Did the characters belong to the same age group/social context as those being referred to/discussed in the passage? Describe how they are similar.

- Do you find the language or the text structure of it similar to that of the present one? Describe how they are similar.

By the text-to-world connections, the students were expected to think beyond the text they read and to connect the themes with larger life/world issues. Obviously these issues were expected to include social and political problems related to historical or current events. This had an intention of projecting literature to them as a tool for forming opinions about social and political issues. One can very well understand that to convey certain messages and to illustrate perspectives on world events is one of the purposes behind every literary text. The author's intention, says Moreillon, should therefore be one of the ingredients of the meaning made by the reader. The following questions were thus framed to activate the text-to-world interaction in the students:

- What message, according to you, is the author trying to convey through this text?

- Do you find any connections between the author's message and the thoughts/ideas about the way of the world? What do you already know about these issues?

- What, according to you is the author's opinion/view about world issues as expressed in the text? Do you agree with this view? Why or why not?

It was equally important to introduce exercises with no single straightforward answer because such an exercise would need the students to activate not only their powers of judgment and appreciation, but if extended to cover other reading skills, such exercises would bring in greater discussion and reflection on the text. The researcher tried to satisfy the needs of the learner as to what s/he was expected to do with the text. It was necessary to keep in mind that we rarely answer questions after reading a text in our regular life but we may need to reply to a letter, follow directions, make a choice, solve a problem, complete the information given from some previous knowledge, etc.

\section{FINDINGS AND DISCUSSION}

In connection with the passage assigned to the students for comprehension by the researcher for this study, following interactions between the students' background knowledge and the text were activated: 


\section{A) Before Reading} (Passage 1)

The students found it a little difficult to fully respond to the topic of the passage. Set in a foreign context with strange names and vocabulary, they were slightly afraid to infer meaning/to interpret the gist of the passage initially. Even after the researcher tried to activate their background knowledge by eliciting responses, they found it a little difficult to interpret what the author was trying to express through the passage. Then the teacher-researcher had to help them in building their background knowledge. She had to ask various questions relating to the vocabulary used in the first paragraph as well as the location where the incident mentioned in the passage had taken place. This attempt by the teacher could achieve the desired results, i.e., the students could lead themselves to the context as well as the gist of the passage. The students could relate the incident discussed to a similar such incident in the life of somebody related to them; possibly people they knew had been through such a situation though they might not regularly come across such incidents in society.

The students came to know that the passage was about the growing violence among teenagers/adolescents and the way in which it could be tackled. They could guess the nationwide scope of this social problem because the passage mentioned that different parts of the nation faced various forms of teenage violence. This was apparent to them even at the first preliminary reading and this connection helped them to prepare for the theme of the passage.

\section{(Passage 2)}

As compared to the first passage, the researcher could easily and quickly activate the background knowledge of the students as the passage was set in a context familiar to them. The first sentence in the passage as well as the introduction to the source of the passage given at the end could help the students identify that the passage was about the incident of early marriage in the life of a great national hero of their country and also about his views on the custom of child marriage in his community. They could relate the topic/incident discussed to similar such incidents taking place in their family circles or in the neighborhood and could even empathize with the characters mentioned.

Right at the beginning of this passage, the author used appropriate vocabulary for personal expression about the child marriages prevalent in those times. This helped the students to guess that the passage was a narrative-cumcomment on the common custom of child marriages in the Kathiawad region of Gujarat, India. The students could realize that the author, Mahatma Gandhi, while narrating an incident in his own life, was also trying to comment on the suffering caused by such social customs.

\section{B) During Reading}

(Passage 1)

The students could not immediately relate to the gang problems mentioned in the passage. However, they could recall similar incidents that they had heard about 
in India: senior citizens being murdered by jobless adolescents, the heinous incident of the gang rape of Nirbhaya in Delhi in which a teenager was involved, as well as the brutal rape by a teenager in Mumbai. This incident was partially recalled by them because the teenager was convicted on the grounds that the brutality of the crime weighed him equal with the other adult offenders. The students couldn't, however, openly talk about any incidents of violence that might have taken place in their neighborhood or in their family.

\section{(Passage 2)}

The students could relate the idea of child marriage to the stories they heard from the elders in the family about how they had got married at an early age. They also realized that instances of such marriages were still taking place in rural areas in India and sometimes even in their own neighborhood in the cities. Most of the students belonged to a social background where early marriages were a common phenomenon due to various reasons like financial poverty, lack of higher education etc. They could therefore empathize with the author and other characters who had faced this situation as mentioned in the passage. However, almost all of them agreed with the author's opinion that this custom was a wrong practice. They all represented the young generation in this social strata and therefore realized the importance of higher education; they recognized that early marriage would prove to be an obstacle to adequate education.

These connections helped the students to project themselves into the situations described in the passages. This led to better understanding of the ideas and opinions expressed by the authors. For the first passage, the students could further think of ways of treating the adolescent offenders and the reasons for the same. Establishing such connections helped the students to realize that even though people live in different places, they may experience the same feelings, and similar social problems. The passages were thus made more interesting and more personally relevant for the students.

\section{IMPLICATIONS OF THE STUDY}

The challenges faced by a teacher in a developing country like India are enormous despite the support of technological equipments like language laboratories and other audio visual teaching materials. Use and handling of such technological aids may be another difficulty in many of the colleges, especially in rural areas.

What is suggested here is that the traditional mechanical "display" questions that are used for reading comprehension should be replaced by more truly communicative activities. By encouraging self to text communication in the students, each student brings in and conveys their own unique experience to the rest of the class. This brings the task of reading closer to real life communication, and integrates the skills of reading and speaking.

This paper therefore suggests strategies for facilitating reading comprehension by developing a series of questions that help the students to make text to self-connections. In talking about these connections, the students not only develop a better understanding of the text but also learn to speak and express 
personal experiences and emotions. This simultaneously addresses one of the major challenges of communicative language teaching, developing speaking skills. In struggling with the reading text, the student learns to communicate in the true sense of the term. Thus, by exploring new creative ways of teaching, a teacher can truly succeed in addressing the multiple intelligences hidden in a classroom.

\section{REFERENCES}

Al-Issa, Ahmad. (2006). Schema Theory and L2 Reading Comprehension: Implications for Teaching. Journal of College Teaching and Learning, 3(7).

Bereiter, C. , Bird, Marlene. (1985). Use of Thinking Aloud in Identification and Teaching of Reading Comprehension Strategies. Cognition and Instruction, 2(2).

Blickenstaff, J., Hallquist, E., \& Kopel, K. (2013). The Effects of Reading Strategies in Comprehension for Elementary Age Learners. Retrieved from http://sophia.stkate.edu/cgi/viewcontent.cgi?article=1001\&context=maed

Johnson, Dale D. (1984). An Investigation of the Effects of Prior Knowledge and Vocabulary Acquisition on Passage Comprehension, Program Report 84-5.. files.eric.ed.gov/fulltext/EO254830.pdf.

Gilakjani, A.P., Ahmadi, S.M. (2011). The Relationship Between L2 Reading Comprehension and Schema Theory: A Matter of Text Familiarity. International Journal of Information and Education Technology, 1(2)

Johnson, Patricia. (1982). Effects on Reading Comprehension of Building Background Knowledge. TESOL QUARTERLY, 16(4).

Meurer, Jose Luiz. (1991). Schemata and Reading Comprehension. https://periodicos.ufsc.br/index.php/desterro/article/viewFile/11574/11211.

Moore, David W. (n.d.). Reading Comprehension Strategies. Retrieved from http://www.ngsp.net/Portals/0/Downloads/HBNETDownloads/Edge_Mono_Mo ore1.pdf

Moreillon, Judi. (2007). Collaborative Strategies for Teaching Reading Comprehension Maximising Your Impact. Chicago: American Library Association.

Richards, Janet; Gipe, Joan P. (1992). Activating Background Knowledge: Strategies for Beginners and Poor Readers. The Reading Teacher. Vol. 45, No.6. www.jstor.org/stable/20200900.

Richardson, Nicole. (2010). Guided Reading Strategies for Reading Comprehension. fisherpub.sjfc.edu/cgi/viewcontent.cgi?article.

WENG, Pei-shi. (2012). The Effect of Background Knowledge on EFL Learners' Reading Comprehension. Sino-US English Teaching. 9(9).

Xiao-hui, LI, Jun, WU, Wei-hua, WANG. (2007). Analysis of Schema Theory and Its Influence On Reading. US-China Foreign Language. 5(1). citeseerx.ist.psu.edu/viewdoz/download?doi.

Young, Dolly. (1991). Activating Student Background Knowledge in a Take Charge Approach to Foreign Language Reading. Hispania. Vol.74, No.4. http://www.jstor.org/stable/343781. 


\section{Shubhada K. Deshpande}

Asst. Professor, Vikas College of Arts, Science\& Commerce, Vikhroli (East), Mumbai, India

The author is a practicing teacher of Communication Skills in English and Business Communication as well as a researcher in ELT. She teaches at Vikas College of Arts, Science \& Commerce, Vikhroli $€$, Mumbai affiliated to University of Mumbai. She is presently involved with a Ph.D. research study in ELT at the PG Dept of English, SNDT Women's University, Churchgate, Mumbai. Developing non-native learners' communication skills in English and methodology for developing their speaking skills in English are her areas of focus.

\section{Passages Chosen for the Study: \\ Passage 1.}

Until two years ago, Clearing, Illinois was a tranquil suburb of Chicago. But residents grew alarmed when they noticed armed teenagers on the streets, giving gang signals and shouting at passing cars. Then came a series of burglaries and graffiti messages on storefronts. By the time local authorities realized they had a gang problem, it was too late. Last December, two 13-year-old girls were shot outside their school as they sat in a car with two members of a local gang, the Ridgeway Lords.

Nearly all 50 states have recently passed laws that allow youths aged 14-17 to be tried in court as adults. In about 25 states they have passed laws to punish parents for their children's behaviour. And in 146 of the nation's largest cities, they have imposed curfews to reduce juvenile violence. When you look at the spectacular rise of violent crime among young people recently, it's easy to understand the concern. Over the past decade, there has been a decline in adult murders in the US, while murder rates have surged for youths between 14-17.

For young offenders who aren't sent to prison, the punishments vary: some are ordered to perform community service, others are placed in job training programs, still others sent to youth prisons. But the Republicans in Congress want to reverse a basic principle of juvenile justice: the separation of young criminals from hardened adult criminals in prison. The reasons are partly financial - to reduce the cost of having separate prisons for young people - and partly psychological - to end what Republicans consider as society's overly protective attitude towards young criminals.

Questions

1. Name the place where the gangs of teenagers started troubling people on the road. Was it a city?

Yes/No. Write the sentence/phrase in support of your answer.

2. Did the incident of gang attack take place all of a sudden? Which sentence tells you so?

3. How do the laws across the nation treat the offenders in incidents of teenage violence? 
4. List down the ways of punishing young offenders.

5. What are the Republicans in Congress against? Why?

6. State whether the following statements are true or false.

a. Ridgeway Lords is the name of a school in U.S.

b. The statistics show a growth in the number of murders by youth in US in last ten years.

c. Republicans in Congress want the young criminals to be separated from the adult criminals in prison.

d. In US, all young offenders are sent to jail.

7. Narrate to your desk mate an incident you know about in which an adolescent boy was involved.

8. Write a paragraph describing the incident narrated to you by your desk mate.

9. You have been appointed a students' representative member on the counselling cell of your college. Write down a list of at least 5 suggestions that you would make to the cell as preventive measures against the students being drawn towards crime and violence.

10. Write a letter to the editor of a newspaper suggesting ways to check the increasing involvement of teenagers in crime and violence.

11. Divide the class into two halves.

a. One of the groups should speak in support of the following proposition:

"Increasing isolation of teenagers from the family leads to their involvement in social evils."

b. The other group should argue against this statement supporting the following proposition:

"Increasing influence of electronic gadgets and over- exposure to violence and crime in the electronic and print media is the main cause of youngsters falling prey to such negative channelization of their

Passage 2. energy."

It is my painful duty to record here my marriage at the age of thirteen. As I see the youngsters of the same age about me were under my care, and think of my own marriage, I am inclined to pity myself and to congratulate them on having escaped my lot. I can see no moral argument in support of such a preposterously early marriage.

Let the reader make no mistake. I was married and not betrothed. For in Kathiawad, there are two distinct rites- betrothal and marriage. Betrothal is a preliminary on the part of the parents of the boy and the girl to join them in marriage, and it can be broken. The death of the boy entails no widowhood on the girl. It is an agreement purely between the parents and the children have no concern with it. Often they are not even informed of it. It appears that I was betrothed thrice, though without my knowledge. I was told that two girls chosen for me had died in turn and, therefore, I infer that I was betrothed three times. I have a faint recollection, however, that the third betrothal took place in my seventh year. But I do not recollect having been 
informed about it. In the present chapter I am talking about my marriage of which I have the clearest recollection.

It will be remembered that we were three brothers. The first was already married. The elders decided to marry my second brother, who was two or three years my senior, a cousin possibly a year older, and me, all at the same time. In doing so there was no thought of our welfare, much less of our wishes. It was purely a question of their own convenience and economy.

\section{Questions}

1. What does Gandhiji feel it is his duty to record?

2. Choose the correct answer.

'My lot' means
a) The lottery won by me.
b) the unfortunate incident of my early marriage
c) my unhappy marriage

3. Write a letter to your friend expressing your views on early marriages

4. Complete the following story:

Uma was a very intelligent student in $4^{\text {th }}$ standard. All the teachers used to like her for being very sincere in studies and very active in all the school activities. Poor family background could never create a hurdle in this enthusiastic girl's deep interest in studies and school activities.

On Monday, however, all of her classmates and the maths teacher were startled to hear from Meera, her close friend and neighbour, that they wouldn't see Uma in the classroom hereafter as she was getting married on Wednesday....

5. The class is to be divided into two halves. The first group should draft the script for a street play to be presented on the topic "Educate and Empower Your Daughter. Marriage can wait."

The second group should enact the play. 